\title{
Micronucleus assay using DNA Specfic and non specific stains in exfoliated oral epithelial cells as a biomarker to assess cytogenetic damage in petrol station attendants
}

\author{
Pulkit Gupta $^{1}$, Aamna Khan ${ }^{2}$, Saurabh Juneja ${ }^{3}$, Anshi Jain ${ }^{4, *}$, Nikita Gulati ${ }^{5}$ \\ ${ }^{1,3}$ Interns, ${ }^{3,4}$ Readers, ${ }^{5}$ Senior Lecturer, Dept. of Oral Pathology and Microbiology, ITS Centre for Dental Studies \& Research, Murdnagar, \\ Ghaziabad, India
}

*Corresponding Author: Anshi Jain

Email: dranshijain@gmail.com

\begin{abstract}
Introduction: Micronuclei are intracytoplasmic chromatin bodies seen as a result of cytogenetic damage or mitotic abnormality. Assessment of micronuclei in exfoliated oral epithelial cells is a marker for genotoxic damage due to various reasons such as lifestyle factors such as alcohol, tobacco and areca nut, occupational exposure to chemical carcinogens and radiation.

Aim and objectives: The aim of the study was to assess the micronuclei count in oral cytosmears of petrol station attendants chronically exposed to petroleum vapors using DNA specific and non specific stains.

Materials and Methods: 40 subjects in the study group working in petrol pump stations for more than 5 years and 40 healthy subjects in the control group without any history of past occupational exposure to petroleum products were included in the study. Percentage micronuclei count and micronuclei index were calculated after observing 1000 cells in oral cytosmears prepared from buccal mucosa of each subject and stained with Papanicolaou (PAP- non DNA specific stain) and Acridine orange stain(DNA specific stain).

Results: Percentage micronuclei count and micronuclei index were increased in study group as compared to the control group. The results were statistically significant. The values were lower in smears stained with DNA specific stain (acridine orange) as compared to non DNA specific stain(PAP).

Conclusion: Micronuclei assay is useful tool to assess and monitor cytogenetic damage due to occupational exposure to petroleum vapors in petrol station attendants. DNA specific stains are better as compared to non DNA specific stains in evaluation of micronuclei.
\end{abstract}

Keywords: Biomarker, Cytogenetic damage, Exfoliative cytology, Micronuclei.

\section{Introduction}

Markers of cellular and molecular changes, respectively, which are associated with the process of carcinogenesis, but which occur even before a malignant transformation takes place, are called biomarkers. ${ }^{1}$ Genomic damage in human cells is the prerequisite for disease development, including cancer. It may be produced by multiple agents such as environmental genotoxins, radiation, chemicals, lifestyle factors such as alcohol, smoking, drugs, stress and genetic factors. Assessment of this genomic damage can be utilized as an effective tool for diagnosis and monitoring with therapeutic value. ${ }^{2}$

Cytogenetic markers like chromosomal aberrations, sister chromatid exchanges, and micronuclei (MN) are sensitive indicators of genetic damage. Micronuclei (MN) are small chromatin bodies that appear in the cytoplasm by the condensation of acrocentric chromosomal fragments or by whole chromosomes, lagging behind the cell division or the loss of chromatin in the main nucleus due to a mutagenic exposition. ${ }^{3-5}$ Thus, it is the only biomarker that allows the simultaneous evaluation of both clastogenic and aneugenic effects in a wide range of cells, which are easily detected in interphase cells. ${ }^{4,6}$ Buccal cells form the first barrier for the inhalation or ingestion route and are capable of metabolizing proximate carcinogens to reactive products. Therefore, it could be argued that oral epithelial cells represent a preferred target site for early genotoxic events induced by carcinogenic agents entering the body via inhalation and ingestion. ${ }^{2}$ The buccal mucosal cells are the first targets due to inhalation of such vapours. ${ }^{7}$ Buccal mucosal cells can be easily collected and studied as they are exfoliated in the process of physiological maturation and desquamation. $^{8}$ The cytological details can be studied through either DNA specific stains(example acridine orange, feulgen stain) or non specific stains(example giemsa stain, PAP stain). ${ }^{9}$

Exposure to gasoline vapours is classified by the International Agency for Research on Cancer (IARC) as possibly carcinogenic to humans, mainly on the basis of the well-established carcinogenicity of some components such as benzene (IARC, 1989).Petrol station attendants who are occupationally exposed to such gasoline vapours are exposed to increased genotoxic risk as compared to other individuals. $^{7}$ The purpose of this study was to assess the effect of genotoxic damage produced by gasoline vapours in petrol pump attendants through micronucleus assay in exfoliated buccal mucosal cells and to ascertain its role as a potential biomarker to determine the genotoxic damage in these individuals.

\section{Materials and Methods}

The study comprised of 40 subjects in the study group who were working in petrol pump stations for more than 5 years and 40 healthy subjects in the control group without any history of past occupational exposure to petroleum products. Written informed consent was obtained from all the subjects. Inclusion criteria was those subjects with more than 5 years history of occupational exposure at petrol pumps were included in the study. Exclusion criteria was those subjects who worked in any other chemical industry in 
the past and those who did not give consent to be a part of the study. Each subject was asked to rinse their mouth with saline and oral cytosmears were prepared from the buccal mucosa of each subject by scraping with wooden spatula, smeared onto a clean glass slide, air dried and fixed immediately with a spray fixative containing 95\% alcohol. The slides were then stained with Papanicolaou (PAP) stain and acridine orange (AO) stain and mounted with DPX.

\section{Micronuclei assessment}

The smears were then viewed under research microscope (Olympus, BX 53) under high magnification (X400 and $\mathrm{X} 1000$ ) and micronuclei were observed in exfoliated oral epithelial cells according to the criteria defined by Tolbert et al.(1992).[3] 1000 epithelial cells in each smear were observed and the presence of micronucleated cells(MNC) and micronuclei frequency(MF). Percentage of micronuclei (number of micronuclei per 100 cells) and Micronuclei index $(\mathrm{MNI}=$ Micronuclei frequency/Total number of Micronucleated cells) were calculated and compared to the controls. The micronuclei observations were also correlated to the occupational history of the study group.

\section{Statistical analysis}

The results were analyzed statistically using SPSS v.17 software using paired T test and ANOVA test. p values less than 0.05 were considered statistically significant with $95 \%$ confidence interval.

\section{Results}

The mean age of the subjects in study group was $39.15 \pm 5.08$ years and in control group was $33.35 \pm 7.39$ years. The mean occupational history of the subjects in the study group was 9.25 \pm 3.32 years (Table 1 ). The percentage micronuclei count was higher in the study group $(1.34 \pm 0.61$ with acridine orange stain and $1.95 \pm 0.72$ with PAP stain) as compared to the control group $(0.175 \pm 0.16$ with acridine orange stain and $0.185 \pm 0.13$ with PAP stain). The results were statistically significant $(\mathrm{p}<0.001)$ (Table 2$)$. The micronuclei index was also higher in the study group $(1.74 \pm 0.37$ with acridine orange stain and $1.82 \pm 0.42$ with PAP stain) as compared to the control group $(1 \pm 0.28$ with acridine orange stain and 1.01 \pm 0.69 with PAP stain). The results were statistically non-significant $(\mathrm{p}>0.05)$ (Table 3$)$. Additionally, the exfoliated cells showed other nuclear abnormalities such as hyperchromatism, altered nucleo-cytoplasmic ratio, karyorhexis and binucleation. The percentage micronuclei count and micronuclei index were observed to be increasing with increasing occupational exposure to petroleum vapours (Table 4). Micronuclei observed are shown in Fig. 1 (PAP stain) and Fig. 2 (Acridine orange stain).

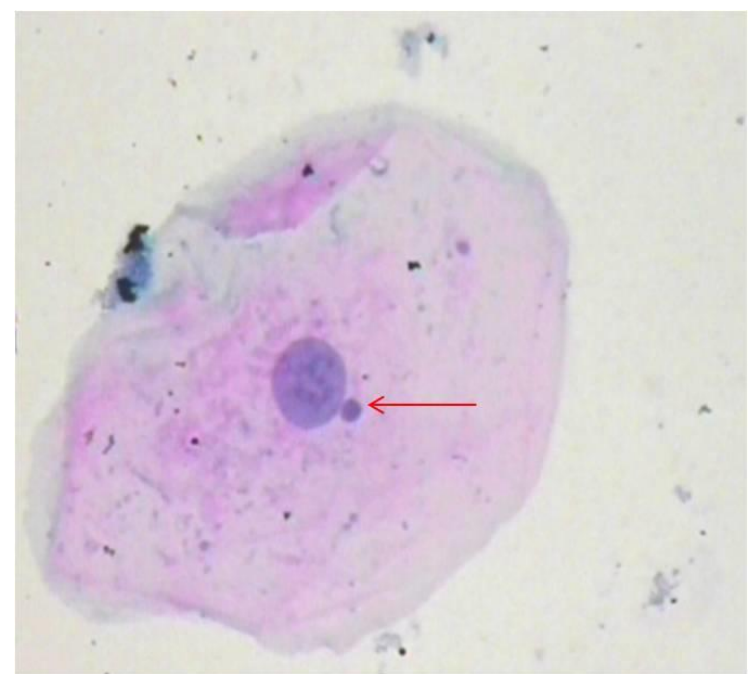

Fig. 1: Micronuclei observed in exfoliated oral epithelial cells (PAP stain, 100x magnification)

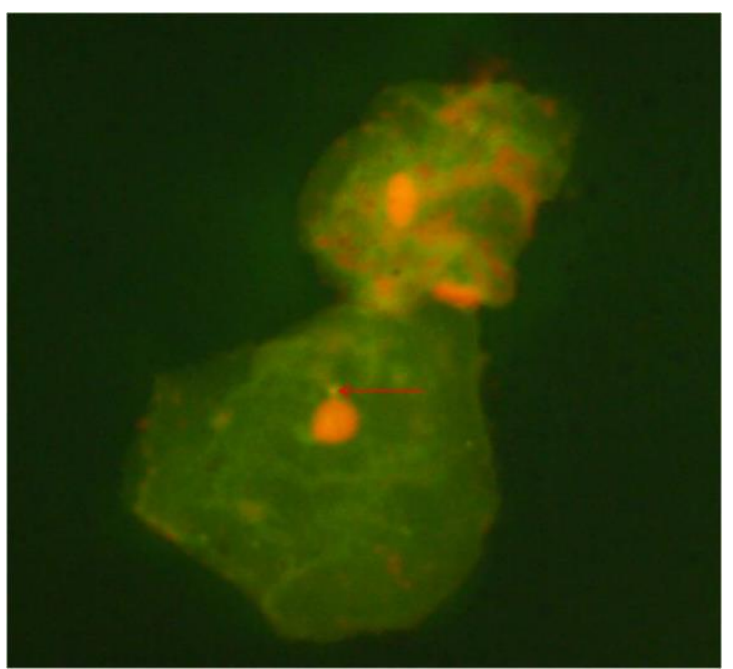

Fig. 2: Micronuclei observed in exfoliated oral epithelial cells (Acridine orange stain, 100x magnification)

Table 1: Age and duration of occupational history in control and study groups

\begin{tabular}{|l|c|c|c|c|}
\hline \multirow{2}{*}{ Age } & & N & $\begin{array}{c}\text { Mean age } \\
\text { (in years) }\end{array}$ & SD \\
\hline \multirow{2}{*}{ Occupational History } & Study Group & 40 & 39.15 & 5.082 \\
\cline { 2 - 5 } & Control & 40 & 33.35 & 7.392 \\
\cline { 2 - 5 } & Study Group & 40 & 9.25 & 3.319 \\
\hline
\end{tabular}


Table 2: Percentage Micronuclei count in Control and study group using Acridine orange and PAP stain

\begin{tabular}{|l|c|c|c|}
\hline & Percentage Micronuclei count & \\
\hline AO & Study Group & Control & p value \\
\hline PAP & $1.34 \pm 0.61$ & $0.175 \pm 0.16$ & 0.000 \\
\hline p value & $1.95 \pm 0.72$ & $0.185 \pm 0.13$ & 0.000 \\
\hline Student T test, $p$ value $\leq 0.05$ statistically significant & 0.000 & 0.675 & \\
\hline
\end{tabular}

Table 3: Micronuclei index in Control and study group using Acridine orange and PAP stain

\begin{tabular}{|l|c|c|c|}
\hline & \multicolumn{2}{|l|}{ Micronuclei index } & \\
\hline AO & Study Group & Control & p value \\
\hline PAP & $1.74 \pm 0.37$ & $1 \pm 0.28$ & 0.000 \\
\hline p value & $1.82 \pm 0.42$ & $1.61 \pm 0.69$ & 0.162 \\
\hline Student T test, $p$ value $\leq 0.05$ statistically significant & 0.208 & 0.002 & \\
\hline
\end{tabular}

Table 4: Correlation of percentage micronuclei and Micronuclei index to duration of occupational history

\begin{tabular}{|l|c|c|c|c|c|}
\hline & & \multicolumn{2}{|c|}{ Acridine orange stain } & \multicolumn{2}{c|}{ PAP stain } \\
\hline Duration of Occupational history & $\mathbf{N}$ & $\begin{array}{c}\text { Percentage } \\
\text { micronuclei count }\end{array}$ & $\begin{array}{c}\text { Micronuclei } \\
\text { index }\end{array}$ & $\begin{array}{c}\text { Percentage } \\
\text { micronuclei count }\end{array}$ & $\begin{array}{c}\text { Micronuclei } \\
\text { index }\end{array}$ \\
\hline 0-5 Yrs. & 46 & 0.26 & 1.23 & 0.34 & 1.73 \\
\hline 6-10 Yrs. & 21 & 1.07 & 1.70 & 1.69 & 1.77 \\
\hline $\mathbf{1 1 - 1 6}$ Yrs. & 13 & 2.03 & 1.68 & 2.66 & 1.78 \\
\hline Total & 80 & 0.76 & 1.49 & 1.07 & 1.76 \\
\hline p value(ANOVA) & & 0.000 & 0.001 & 0.000 & 0.942 \\
\hline
\end{tabular}

ANOVA test, $p$ value $\leq 0.05$ statistically significant

\section{Discussion}

Micronuclei represent small, additional nuclei formed by the exclusion of chromosome fragments or whole chromosomes lagging at mitosis caused by genotoxins/carcinogens. ${ }^{7,10}$ Micronuclei assay is a simple, non invasive and inexpensive tool to assess genotoxic damage in an individual. Circulating lymphocytes have been investigated previously for micronuclei assessment in head and neck cancer cases. ${ }^{11,12}$

Oral exfoliative cytology is based on the principle that oral squamous cells have physiological propensity to exfoliate in the process of cell turn over following cell maturation. Evaluation of oral exfoliated cells for micronucleated cells and micronuclei frequency forms a promising means to evaluate genotoxic damage. Ease of accessibility and procurement of smears adds to the advantages of oral exfoliated cells as an excellent methodology to study genomic damage.

Micronuclei count in exfoliated oral epithelial cells have been observed to be significantly associated with oral hygiene and dental factors, ${ }^{5}$ systemic disorders such as diabetes mellitus, ${ }^{13}$ environmental and occupational exposure, ${ }^{7}$ tobacco related habits such as smoking, gutkha and paan/areca nut chewing, ${ }^{4}$ oral potentially malignant disorders and oral cancer. ${ }^{14,15}$

Petrochemical products and its products, principally benzene have been classified as known carcinogens. Exposure to benzene has been associated with acute myeloid leukemia and Hodgkin's lymphoma. ${ }^{16}$ Exposure to these products can be environmental (as vehicle pollutants and cigarette smoke) or occupational (workers in petrochemical industries and refineries). Petrol pump station attendants are exposed to organic chemicals such as benzene vapors during refilling and handling of petrol. Therefore, they are at a higher risk of acquiring genotoxic damage due to occupational exposure from inhalation of the volatile components of petroleum. ${ }^{7}$

The results of our study show significantly increased levels of micronucleated cells and micronuclei frequency in petrol pump station attendants, which could be attributed to occupational exposure to petrochemical products and its vapors. However, Hadnagy et al. ${ }^{17}$ have stated that these workers are not only exposed to petrochemical vapors directly, but also those through vehicular emissions and environmental pollution. ${ }^{7}$ This could also contribute to the increased cytotoxic damage in these subjects.

Our results are in accordance with a previous study by Celik et al. ${ }^{7}$ who have also shown increased MN frequencies in exfoliated buccal cells between exposed workers (1.34 \pm $0.80)$ and control subjects $(0.47 \pm 0.03)$. Bukvic et al. ${ }^{18}$ also observed significant difference in $\mathrm{MN}$ count in peripheral lymphocytes of petrol station attendants. However, there are studies with divergent results indicating no correlation of exposure to petroleum vapors to cytogenetic damage. Surralles et al. ${ }^{19}$ reported no significant difference in the frequency of cytogenetic damage between benzene exposed workers and controls in the buccal cells and lymphocytes. Bukvic et al. ${ }^{18}$ Carere et al. ${ }^{20}$ and Pitarque et al. ${ }^{21}$ showed that there was no significant difference between controls 
and experimental subjects in evaluation of SCE frequencies in petrol station attendants.

Celik et al. ${ }^{7}$ have shown that the urinary phenol levels to be elevated in individuals exposed to petroleum products. However, estimation of urinary phenol has a limitation of requirement of high exposure to benzene and being affected by other factors such as diet and drugs. Qu et al. ${ }^{22}$ have recommended analysis of other urinary biomarkers such as trans, trans-muconic acid and S-phenylmercapturic acid for bimonitoring of low level benzene exposure.

Our study showed lower MN count and frequency with acridine orange stain (DNA specific stain) as compared to PAP stain (non DNA specific stain). It is difficult to differentiate intracellular structures from micronuclei when non DNA specific stains are used, therefore often leading to over estimation of MN count. These intra cellular structures are not detected with the DNA-specific stain which specifically stains the nucleic acid component, therefore being more specific. ${ }^{9}$ Therefore, DNA specific stains are more precise in identifying the micronuclei as non DNA specific stains provide false high values for micronucleated cells and frequency.

\section{Conclusion}

Micronuclei (MN) assay has a definite advantage in terms of simplicity, less ease technique sensitive, economical and minimum time consuming procedure. $\mathrm{MN}$ assay can be used as a simple chairside or mass screening method to assess and identify patients with early genomic damage. The present study ascertains the role of micronuclei assay and oral exfoliative cytology in biomonitoring the genotoxic changes in oral epithelial cells in subjects with occupational exposure to petroleum vapors in petrol pump station attendants. Application of DNA specific stains can increase the sensitivity of the assay in detecting micronuclei in exfoliated buccal cells.

\section{Source of funding}

None.

\section{Conflict of interest}

None.

\section{References}

1. Girod SC, Pfeifer P, Ries J, Pape HD. Proliferative activity and loss of function of tumor suppressor genes as "biomarkers" in diagnosis and prognosis of benign and preneoplastic oral lesions and oral squamous cell carcinoma. Br J Oral Max Surg 1998;36:252-60.

2. Kashyap B, Reddy PS. Micronuclei assay of exfoliated oral buccal cells: Means to assess the nuclear abnormalities in different diseases. J Can Res Ther 2012;8:184-91.

3. Tolbert PE, Shy CM, Allen JW. Micronuclei and other nuclear anomalies in buccal smears: Methods development. Mutat Res 1992;271:69-77.

4. Fareed M, Afzal M, Siddique YH. Micronucleus investigation in buccal mucosal cells among pan masala/gutkha chewers and its relevance for oral cancer. Biol Med 2011;3(2):8-15.
5. Bloching M, Reich W, Schubert J, Grummt T, Sandner A. Micronucleus rate of buccal mucosal epithelial cells in relation to oral hygiene and dental factors. Oral Oncol 2008;44:220- 6 .

6. Moore LE, Warner ML, Smith AH, Kalman D, Smith MT. Use of fluorencent micronucleus assay to detect the genotoxic effects of radiation and arsenic exposure in exfoliated human epithelial cells. Environ Mol Mutagen 1996;27:176-84.

7. Celik A, Cavas T, Ergene-Gozukara S. Cytogenetic biomonitoring in petrol station attendants: micronucleus test in exfoliated buccal cells. Mutagenesis 2003;18(5):417-21.

8. Kamath VV, Anigol P, Setlur K. Micronuclei as prognostic indicators in oral cytological smears; comparison between smokers and non-smokers. Clin Cancer Investig J 2014;3:4954.

9. Nersesyan A, Kundi M, Atefie K, Schulte-Hermann R, Knasmuller S. Effect of Staining Procedures on the Results of Micronucleus Assays with Exfoliated Oral Mucosa Cells. Cancer Epidemiol Biomarkers Prev 2006;15:1835-40.

10. Uma AN, Dhananjay SK, Aroul T, Singh SB, Lokeshmaran A. Comparative Cytogenetic Study of Exfoliative Oral Mucosal cells in Tobacco related Potentially Malignant Disorders in a South Indian Population. Int J Adv Res Technol 2014;3(8):612 .

11. Minicucci EM, Kowalski LP, Maia MA, Pereira A, Ribeiro LR, de Camargo JL, et al. Cytogenetic damage in circulating lymphocytes and buccal mucosa cells of head-and-neck cancer patients undergoing radiotherapy. J Radiat Res 2005;46:13542.

12. Burgaz S, Coskun E, Cakmak G Demircigil, Aygun N Kocabas, Cetindag F, Sunter O et al. Micronucleus frequencies in lymphocytes and buccal epithelial cells from patients having head and neck cancer and their first-degree relatives. Mutagenesis 2011;26(2):351-6.

13. Zuniga-Gonzalez GM, Batista-Gonzalez CM, Gomez-Meda BC, Ramos Ibarra ML, Zamora-Perez AL, Munozagallanes T, et al. Micronuclei in diabetes: folate supplementation diminishes micronuclei in diabetic patients but not in an animal model. Mutat Res 2007;634(1-2):126-34.

14. Dindgire SL, Gosavi S, Kumavat RM, Ganvir S, Hazarey V. Comparitive study of exfoliated oral mucosal cells micronucleus frequency in potentially malignant and malignant lesions. Int J Oral Maxillofac Pathol 2012;3:15-20.

15. Casartelli G, Bonatti S, De Ferrari M, Scala M, Mereu P, Margarino G, et al. Micronucleus frequencies in exfoliated buccal cells in normal mucosa, precancerous lesions and squamous cell carcinoma. Anal Quant Cytol Histol 2000;22:486-92.

16. Zhang L, Eastmond DA, Smith MT. The nature of chromosomal aberrations detected in humans exposed to benzene. CRC Crit Rev Toxicol 2002;32:1-42.

17. Hadnagy W, Seemayer NH. Cytotoxic and genotoxic effects of extract of particulate emission from a gasoline-powered engine. Environ Mol Mutagen 1988;12:385-96.

18. Bukvic N, Bavaro P, Elia G, Cassano F, Fanelli M, Guanti G. Sister chromatid exchange (SCE) and micronucleus (MN) frequencies in lymphocytes of gasoline station attendants. Mutat Res 1998;415:25-33.

19. Surralles J, Autio K, Nylund L, Jarventaus H, Norppa H, Veidebaum T, et al. Molecular cytogenetic analysis of buccal cells and lymphocytes from benzene-exposed workers. Carcinogenesis 1997;18:817-23.

20. Carere A, Antoccia A, Crebelli R, Degrassi F, Fiore M, Iavarone I, et al. Genetic effects of petroleum fuels: cytogenetic monitoring of gasoline station attendants. Mutat Res 1995;332:17-26.

21. Pitarque M, Carbonell E, Lapena N, Marsa M, Valbuena A, Creus A, et al. SCE analysis in peripheral blood lymphocytes 
of a group of filling station attendants. Mutat Res 1997;390:153-9.

22. Qu Q, Melikian AA, Li G, Shore R, Chen L, Cohen B, et al.

Validation of biomarkers in humans exposed to benzene: urine metabolites. Am J Ind Med 2000;37:522-31.

How to cite the article: Gupta P, Khan A, Juneja S,

Jain A, Gulati N. Micronucleus assay using DNA Specfic and non specific stains in exfoliated oral epithelial cells as a biomarker to assess cytogenetic damage in petrol station attendants. J Dent Specialities 2019;7(2):102-6. 